\title{
KONTAMINASI MERKURI PADA SAMPEL LINGKUNGAN DAN FAKTOR RISIKO PADA MASYARAKAT DARI KEGIATAN PENAMBANGAN EMAS SKALA KECIL KRUENG SABEE PROVINSI ACEH \\ (Mercury Contamination in the Environmental Samples and Risk Factors in Inhabitants of the Small Scale Gold Mining Activities Krueng Sabee Aceh Province)
}

\author{
Sofia $^{1^{*}}$ dan Adi Heru Husodo ${ }^{2}$ \\ ${ }^{1}$ Fakultas Kedokteran, Universitas Syiah Kuala, Darussalam-Banda Aceh 2311. \\ ${ }^{2}$ Bagian Kesehatan Lingkungan dan Kesehatan Kerja, Fakultas Kedokteran, \\ Universitas Gadjah Mada, Jl. Farmako, Sekip Utara, Yogyakarta 55281. \\ *Penulis korespondensi. Tel/Fax : (0651)7551843. Email: sofia_acheh@yahoo.com. \\ Diterima: 23 Desember 2015 \\ Disetujui: 6 Mei 2016
}

\begin{abstract}
Abstrak
Kegiatan penambangan emas skala kecil dengan teknik amalgamasi dapat memberikan peluang introduksi merkuri (Hg) ke lingkungan dan manusia. Penelitian kontaminasi $\mathrm{Hg}$ pada air minum, ikan, rambut kepala manusia, dan faktor risiko pada manusia telah dilakukan di wilayah Krueng Sabee, Provinsi Aceh. Metode pengambilan dan pengujian sampel yang mengandung $\mathrm{Hg}$ dilakukan dengan prosedur SNI, EPA dan WHO. Rancangan cross sectional survey dilakukan pada empat desa dengan 72 responden yang dipilih secara acak. Wawancara dilakukan menggunakan kuesioner terstruktur untuk mendapatkan informasi terkait faktor risiko kesehatan. Pengukuran konsentrasi $\mathrm{Hg}$ untuk sampel air dan ikan dilakukan dengan Cold Vapor Atomic Absorption Spectrophotometer dan untuk sampel rambut kepala menggunakan Inductively Coupled Plasma Mass Spectrometry. Analisis data dilakukan dengan analisis varian, uji t sampel bebas, dan uji t satu sampel. Model prediksi dihasilkan menggunakan analisis regresi linier berganda. Hasil penelitian ini menunjukkan konsentrasi Hg pada sampel air sumur sebesar 0,24 $\pm 0,25 \mu \mathrm{g} / \mathrm{L}$; sampel ikan: Rastrellinger kanagurta,149,46 $\pm 2,00 \mu \mathrm{g} / \mathrm{g}$, Selaroides $s p, 58,6 \pm 3,01 \mu \mathrm{g} / \mathrm{g}$, Euthynnus affinis, 46,3 $\pm 2,98 \mu \mathrm{g} / \mathrm{g}$; dan pada rambut kepala mulai dari 11,2 $\pm 4,02 \mu \mathrm{g} / \mathrm{g}$ hingga 48,3 $\pm 22,29 \mu \mathrm{g} / \mathrm{g}$. Faktor-faktor risiko yang berpengaruh terhadap konsentrasi $\mathrm{Hg}$ pada responden adalah status bekerja di Krueng Sabee, lokasi, lama tinggal, status pekerja tambang dan lama penggunaan pembakar amalgam. Faktor-faktor risiko ini memberi peran sebesar 45,8\% terhadap akumulasi $\mathrm{Hg}$ di dalam rambut kepala responden.
\end{abstract}

Kata kunci: faktor risiko, Krueng Sabee, kontaminasi, merkuri, penambangan emas, rambut manusia.

\begin{abstract}
Small-scale gold mining activities with amalgamation process can contribute the entry of mercury $(\mathrm{Hg})$ into environment and humans. Research on Hg contamination in drinking water, fish, human head hair, and risk factors has been conducted in the area of Krueng Sabee, Aceh Province. Methods of samples collection and Hg concentrations testing conducted by SNI, EPA and WHO procedures. A cross sectional survey was conducted in four villages with 72 respondents which were randomly selected. The interviews were conducted using a structured questionnaire to obtain information related to health risk factors. Measurement of $\mathrm{Hg}$ concentration in drinking water and fish samples were conducted by Cold Vapor Atomic Absorption Spectrophotometer and for head hair sample using Inductively Coupled Plasma Mass Spectrometry. Data analysis was performed by analysis of variance, independent samples t-test and t-test of one sample. Predictive models generated using multiple linear regression analysis. The results showed $\mathrm{Hg}$ concentration in well water was $0.24 \pm 0.25 \mu \mathrm{g} / \mathrm{g}$; in fish samples were: Rastrellinger kanagurta, $149.46 \pm 2.00 \mu \mathrm{g} / \mathrm{g}$, Selaroides sp, $58.6 \pm 3.01 \mu \mathrm{g} / \mathrm{g}$, Euthynnus affinis, $46.3 \pm 2.98 \mu \mathrm{g} / \mathrm{g}$; and in head hair ranging from $11.2 \pm 4.02 \mu \mathrm{g} / \mathrm{g}$ to $48.3 \pm 22.29 \mu \mathrm{g} / \mathrm{g}$. Risk factors that were correlated with respondent's head hair Hg concentration were working in Krueng Sabee, village location, length of stay, role in mining process, and length of contact with amalgamation combustion. These risk factors giving a role of $45.8 \%$ to the accumulation of $\mathrm{Hg}$ in the head hair of respondents..
\end{abstract}

Keywords: contamination, human hair, Krueng Sabee, mercury, risk factors, small-scale gold mining.

\section{PENDAHULUAN}

Kontaminasi merkuri $(\mathrm{Hg})$ masih menjadi permasalahan lingkungan dan kesehatan masyarakat di negara-negara berkembang. $\mathrm{Hg}$ banyak digunakan dalam kegiatan Penambangan Emas Skala Kecil (PESK). Lee dan Lee (2012) mencatat bahwa lebih dari 55 negara, sedikitnya seratus juta orang, bergantung pada kegiatan PESK baik secara langsung maupun tidak langsung. 
Spiegel and Veiga (2005) menambahkan bahwa data dari United Nations Industrial Development Organization (UNIDO) menunjukkan sebanyak 2030 juta pekerja terlibat dalam kegiatan PESK ini.

$\mathrm{Hg}$ digunakan sebagai bahan pengikat emas pada kegiatan penambangan. $\mathrm{Hg}$ dan emas akan berinteraksi membentuk amalgam yang dikenal dengan metode amalgamasi. De Miguel dkk. (2014) menyatakan bahwa metode amalgamasi menggunakan $\mathrm{Hg}$ menguntungkan pekerja tambang karena tidak memerlukan waktu yang lama dalam proses mendapatkan emas. Di samping itu proses ini meminimalkan kehilangan emas yang diekstraksi. Swain dkk. (2007) menambahkan bahwa metode amalgamasi merupakan metode yang paling banyak digunakan pada proses ekstraksi emas. Metode ini tercatat mampu memberikan kontribusi 1000 ton Hg yang dibuang ke lingkungan.

World Health Organization menetapkan $\mathrm{Hg}$ dan senyawaannya sebagai bahan kimia berbahaya dan beracun yang harus dihilangkan dari semua buangan limbah dan pelepasannya ke udara. Kegiatan PESK umumnya tidak menerapkan aturan pembuangan limbah sesuai syarat pembuangan limbah berbahaya. Andri (2011) menyatakan bahwa proses amalgamasi pada aktivitas PESK akan mengakibatkan degradasi lingkungan dari proses pencucian yang dilakukan. Sisa buangan limbahnya dialirkan ke kolam penampungan yang tidak memenuhi syarat yang selanjutnya mengalir masuk ke sungai atau air tanah menuju sumur. Penelitian yang dilakukan di Timika, Papua juga mendapatkan bahwa kegiatan penambangan emas menimbulkan perubahan secara fisik, kimiawi dan biologi pada lingkungan di sekitar lokasi kegiatan (Suharno dkk., 2014).

Proses pembakaran amalgam yang dilakukan dengan panci serta dilakukan tanpa retort dapat menyebabkan uap $\mathrm{Hg}$ mencemari udara. Uap $\mathrm{Hg}$ yang dilepas ke udara tidak hanya dihirup oleh pekerja tambang tapi juga mempengaruhi kesehatan masyarakat di sekitar industri pengolahan (Shandro dkk., 2009). Menurut Clarkson (2002) uap Hg stabil di udara dan mampu bertahan di atmosfer selama 1 tahun. Uap Hg juga mampu terbawa angin hingga ribuan kilometer. Praktik yang dilakukan pada kegiatan PESK ini mengakibatkan pencemaran pada media air, tanah, udara dan kesehatan manusia.

Kecamatan Krueng Sabee Kabupaten Aceh Jaya, Provinsi Aceh merupakan salah satu daerah yang kaya dengan sumber daya alam geologi yang mengandung emas $(\mathrm{Au})$. Proses eksplorasi batuan emas dilakukan di daerah pegunungan Gunung Ujeun sejak tahun 2007 secara tradisional menggunakan peralatan sederhana. Proses pengolahan dilakukan secara amalgamasi menggunakan $\mathrm{Hg}$ dan pembakaran amalgam secara terbuka di area pemukiman penduduk. Kegiatan ini telah memperlihatkan dampak terhadap kerusakan lingkungan dan kesehatan masyarakat. Selama enam tahun kegiatan PESK dijalankan penduduk telah terdokumentasi mengalami sakit kepala, malaria, hipertensi, sakit lambung, batuk, dan sakit pinggang.

Penelitian mengenai dampak merkuri pada kegiatan penambangan emas skala kecil telah dilakukan (Elvince dkk., 2010; Andri, 2011; Olivero-Verbel dkk., 2011; Suhendrayatna dkk., 2011; Charles dkk., 2013). Namun kajian mengenai faktor-faktor risiko pada kegiatan PESK belum banyak dilakukan. Penelitian ini bertujuan untuk menilai paparan $\mathrm{Hg}$ di lingkungan dan manusia serta faktor-faktor risiko yang memengaruhi konsentrasi $\mathrm{Hg}$ di dalam rambut kepala masyarakat. Penelitian ini juga akan membuat sebuah model prediksi konsentrasi $\mathrm{Hg}$ di dalam rambut kepala manusia dari faktor risiko di wilayah penambangan emas skala kecil Krueng Sabee, Aceh Jaya, Provinsi Aceh.

\section{METODE PENELITIAN}

\section{Waktu dan Lokasi}

Waktu penelitian mulai bulan Agustus 2013 sampai April 2014. Penelitian ini dilakukan di wilayah penambangan emas kecamatan Krueng Sabee kabupaten Aceh Jaya, Provinsi Aceh. Rancangan cross sectional survey dijalankan pada empat desa di wilayah Kecamatan Krueng Sabee. Penentuan sampel desa dilakukan secara cluster sampling. Desa terpilih adalah desa Curek, desa Paya Seumantok, desa Panggong, dan desa Panton Makmur. Lokasi sampel penelitian ditampilkan pada Gambar 1.

Secara geografis, desa Curek terletak pada 95'41'45'BT dan 4'37'14'LS, desa Paya Seumantok terletak pada 95039'27'BT dan 4'36'58'"LS, desa Panggong terletak pada 95'40'35'BT dan 4'40'45'LS, dan desa Panton Makmur terletak pada $95^{\circ} 38^{\prime} 55^{\prime \prime}$ BT dan 4'38'40'LS. Aktivitas pengolahan batuan dan pembakaran amalgam dilakukan oleh masyarakat di area pemukiman penduduk (Gambar 2). Aktivitas (a) proses pencucian batuan yang mengandung emas di gelondongan dan (b) pembakaran amalgam secara terbuka, yang dilakukan masyarakat menggunakan metode tradisional.

\section{Prosedur Pengambilan Sampel dan Pengumpulan Data}

Sampel penelitian ini terdiri dari sampel air minum, ikan, dan rambut kepala responden. Sampel 


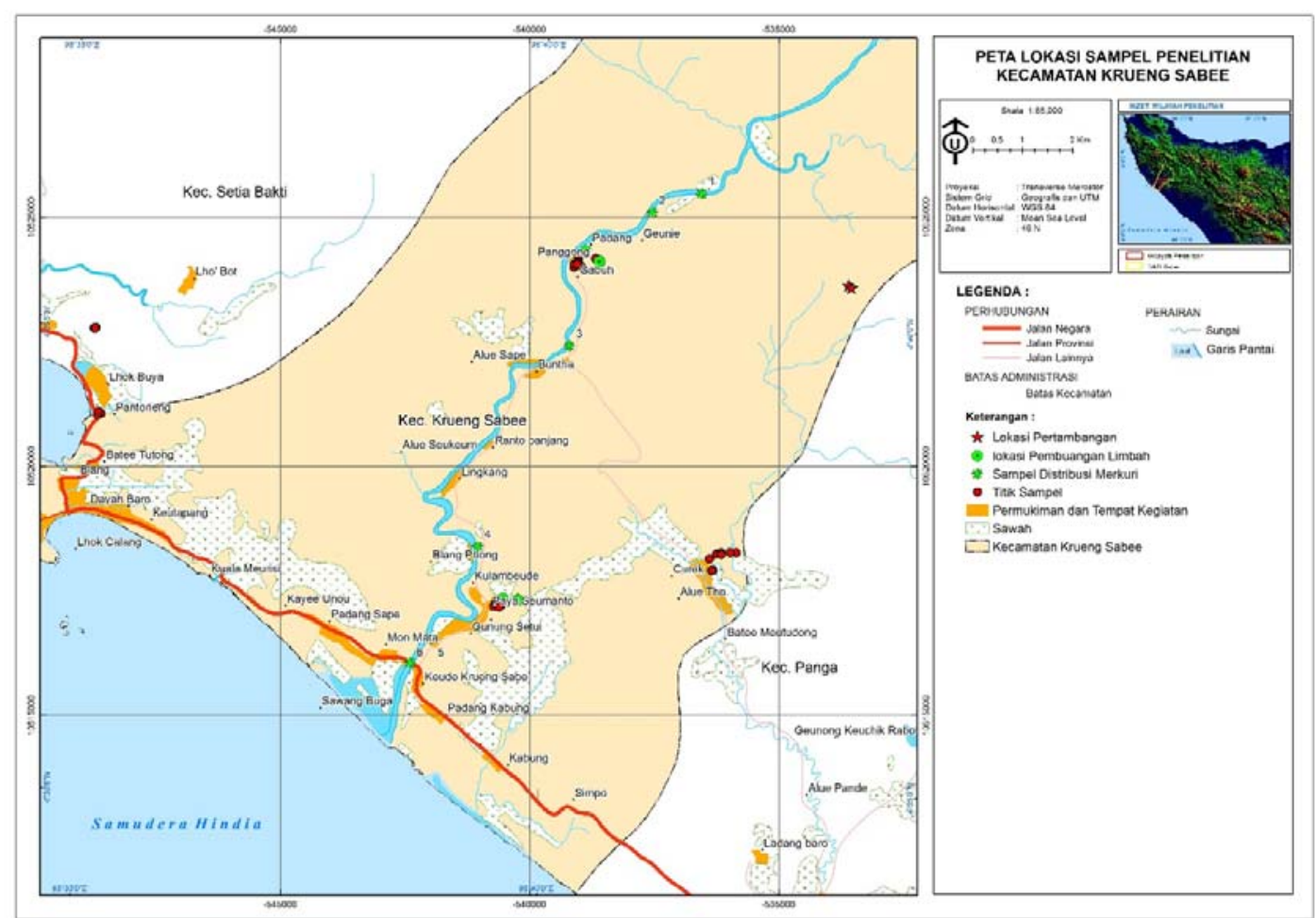

Gambar 1. Lokasi sampel penelitian di wilayah Kecamatan Krueng Sabee, Provinsi Aceh.

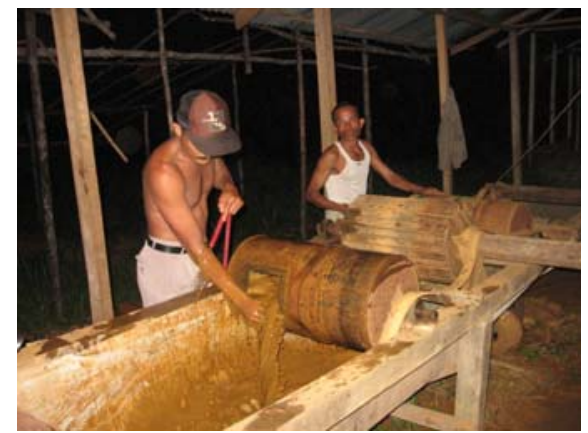

(a)

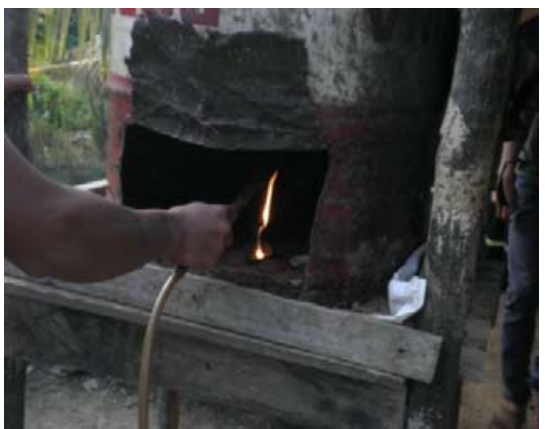

(b)

Gambar 2. Aktivitas pengolahan emas menggunakan merkuri melalui (a) proses pencucian batuan dan (b) pembakaran amalgam.

air minum diambil dari sumber air sumur dan PDAM di wilayah Krueng Sabee. Prosedur pengambilan sampel penelitian ini mengikuti prosedur yang ditetapkan oleh Anonim (1995) dan Anonim (2008). Pengukuran konsentrasi merkuri di dalam sampel air dilakukan menurut Standar Nasional Indonesia, SK SNI M-02-1989-F tahun 1989 serta Standar Nasional Indonesia, SNI 6989.78 tahun 2011. Sampel air dikompositkan dan disimpan dalam botol Nalgene polietilen yang telah dicuci dan dikeringkan. Pengawetan sampel air dilakukan dengan menambahkan $\mathrm{HNO}_{3}$ sebanyak 2 $\mathrm{mL}$ untuk menjamin bahwa sampel tidak rusak dan memenuhi syarat untuk dapat diuji. Sampel selanjutnya disimpan di dalam wadah pendingin. Botol sampel dilengkapi label yang menginformasikan lokasi, waktu, dan koordinat pengambilan sampel.
Sampel ikan dikumpulkan dari pasar tradisional di daerah Krueng Sabee yang dekat dengan pemukiman penduduk. Pemilihan spesies ikan mempertimbangkan jenis yang sering dikonsumsi masyarakat, yaitu ikan kembung (Rastrellinger kanagurta), selar (Selaroides sp), dan tuna (Euthynnus affinis). Sampel ikan yang dikumpulkan langsung dibungkus dengan aluminium foil dan dimasukkan ke dalam plastik yang telah diberi nomor identifikasi. Selanjutnya sampel disimpan dalam kontainer styrofoam yang telah diberi es. Di laboratorium, sampel disimpan pada suhu $-20{ }^{\circ} \mathrm{C}$ sebelum dianalisis.

Sampel rambut kepala dikumpulkan dari 72 orang responden yang telah dipilih dengan metode sampling acak sederhana. Responden terdiri dari pekerja tambang, pekerja pembakar amalgam, dan bukan pekerja tambang. Sampel rambut kepala dikumpulkan sebanyak 100 helai (50-100 mg) yang 
diambil dari daerah oksipital. Rambut kepala yang telah digunting disimpan di dalam plastik yang bertutup.

Untuk menghindari terjadinya kontaminasi saat pengumpulan dan persiapan analisis sampel, peralatan dan botol penyimpan sampel terlebih dahulu dibilas dengan air yang telah dimurnikan. Penggunaan sarung tangan dilakukan pada setiap proses pengumpulan dan penanganan sampel. Di laboratorium semua peralatan setelah selesai digunakan selalu dicuci dengan cairan pencuci Decon dan kemudian direndam lagi ke dalam $\mathrm{HNO}_{3} \quad 10 \%$ selama satu malam untuk menghindarkan kontaminasi silang

Data primer dikumpulkan melalui metode survei yang dilakukan pada responden untuk menggali informasi terhadap proses penambangan dan pengolahan bijih tambang yang dilakukan melalui pengamatan di lapangan. Survei dilakukan juga pada responden melalui wawancara menggunakan kuesioner terstruktur yang dimodifikasi dari Anonim (2008). Data sekunder dikumpulkan dari instansi terkait yang meliputi data kependudukan, data geografi lahan, data jumlah industri pengolahan emas skala kecil, data kesehatan, data hasil survey dinas terhadap kontaminasi merkuri di dalam air di wilayah Krueng Sabee, Aceh Jaya.

\section{Analisis Merkuri}

Total merkuri di dalam sampel air sumur dan PDAM dianalisis sesuai prosedur Standard Methods for the Analysis of Water and Waste Water (Anonim, 1992). Sampel air dianalisis dengan Cold Vapor Atomic Absorption Spectrophotometer (CVAAS). Sampel ikan di destruksi dengan microwave sesuai prosedur yang direkomendasikan CEM Application Note for Acid Digestion.

Sampel ikan dikeringkan di dalam oven dengan suhu $40{ }^{\circ} \mathrm{C}$. Masing-masing spesies ikan dibuat tiga replikat dan ditimbang sekitar $0,5 \mathrm{~g}$ dan dimasukkan ke dalam vessel microwave digester dan ditambahkan $10 \mathrm{~mL} \mathrm{HNO}_{3}$. Sampel dipanaskan pada suhu $200{ }^{\circ} \mathrm{C}$, tekanan 800 psi di dalam microwave MARS selama 15 menit. Setelah proses destruksi sampel selanjutnya diencerkan dalam labu ukur $25 \mathrm{~mL}$ untuk selanjutnya sampel diukur total merkuri dengan CVAAS. Limit deteksi didapatkan $0,01 \mu \mathrm{g} / \mathrm{g}$. Replikasi sampel uji dilakukan secara duplikat. Kadar merkuri dilaporkan dalam berat basah.

Sampel rambut kepala ditimbang $1 \mathrm{mg}$ dan dimasukkan dalam tabung PTFE. Kemudian ditambahkan $\mathrm{HNO}_{3}$ dan dibiarkan 20 menit untuk menghilangkan busa yang muncul. Selanjutnya tabung PTFE dimasukkan ke dalam microwave MDS-2000 dan sampel dihancurkan selama 20 menit. Sampel didinginkan pada temperatur kamar dan dimasukkan ke dalam labu ukur $100 \mathrm{~mL}$ dan dilarutkan dengan $50 \mathrm{~mL}$ air deionisasi. Analisis Hg mengikuti prosedur Knight dkk. (1999) sebelum diukur menggunakan Inductively Coupled PlasmaMass Spectrometry (ICP-MS).

\section{Analisis Statistik}

Data analisis merkuri ditampilkan dalam bentuk rerata \pm simpangan baku. Perbedaan ratarata antara spesies ikan dan kadar merkuri digunakan analisis varian satu jalur dan uji lanjut Least Significant Difference. Perbedaan rata-rata merkuri di dalam rambut kepala dengan nilai ambang batas digunakan uji $t$ satu sampel. Signifikansi statistik di uji dua arah pada $\mathrm{p}<0,05$. Variabel faktor-faktor risiko pada pekerja dan dari kegiatan pengolahan emas disusun sebagai model prediksi menggunakan analisis regresi linier berganda dengan metode Enter. Model terbaik di dapatkan dengan melakukan evaluasi nilai koefisien korelasi berganda, koefisien determinasi, signifikan, koefisien determinasi terkoreksi dan simpangan baku dari penduga.

\section{HASIL DAN PEMBAHASAN}

\section{Merkuri dalam Air Minum dan Ikan}

Total konsentrasi merkuri rata-rata di dalam sampel air minum dan ikan di empat lokasi penelitian ditampilkan pada Gambar 3.Konsentrasi total $\mathrm{Hg}$ di dalam sampel air minum dan ikan pada Gambar 3 menunjukkan kegiatan PESK di wilayah Krueng Sabee telah memberikan dampak pada lingkungan di sekitar lokasi pengolahan. Air minum dari sumber PDAM tidak terdeteksi mengandung $\mathrm{Hg}$, namun sumur warga telah terkena dampak buangan limbah $\mathrm{Hg}$ yang ditunjukkan dengan nilai konsentrasi $\mathrm{Hg}$ rata-rata sebesar $0,24 \pm 0,25 \mu \mathrm{g} / \mathrm{L}$. Meskipun nilai ini masih berada di bawah nilai ambang batas $1 \mu \mathrm{g} / \mathrm{L}$ yang ditetapkan oleh Peraturan Pemerintah No 82 Tahun 2001 namun hal ini menunjukkan kegiatan PESK telah memberi kontribusi buangan limbah yang diserap oleh air tanah yang pada akhirnya mengalir ke sumur penduduk. Hasil yang hampir sama dilaporkan oleh Elvince dkk. (2010) yang melakukan pengukuran konsentrasi $\mathrm{Hg}$ pada air sumur di wilayah yang sama, Krueng Sabee, yaitu berkisar $0,345 \mu \mathrm{g} / \mathrm{L}$ hingga $0,777 \mu \mathrm{g} / \mathrm{L}$. Sumur warga yang menerima pasokan air tanah menerima dampak bahaya dari air yang mengandung $\mathrm{Hg}$ ini jika terus dikonsumsi dalam waktu lama.

Konsentrasi total $\mathrm{Hg}$ rata-rata di dalam ikan menunjukkan bahwa aktivitas PESK telah menyebabkan ikan yang dikonsumsi masyarakat Krueng Sabee mengandung Hg. Nilai konsentrasi 


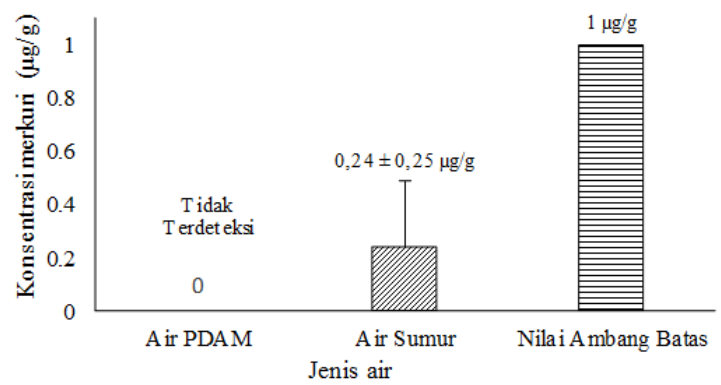

(a)

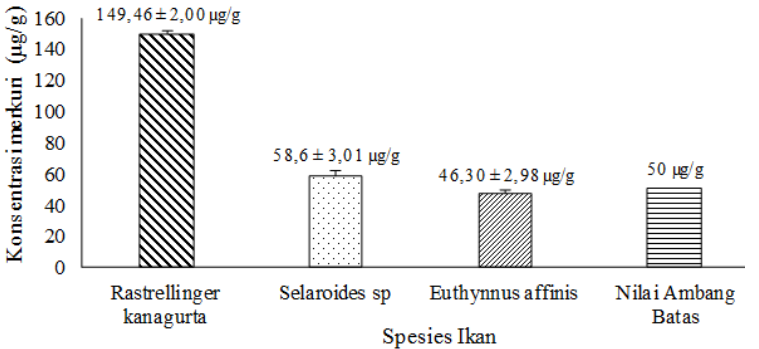

(b)

Gambar 3. Konsentrasi total Hg rata-rata pada (a) sampel air minum dan (b) ikan di wilayah Krueng Sabee dibandingkan nilai ambang batas.

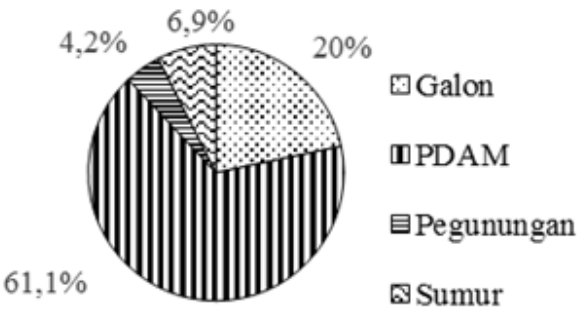

(a)

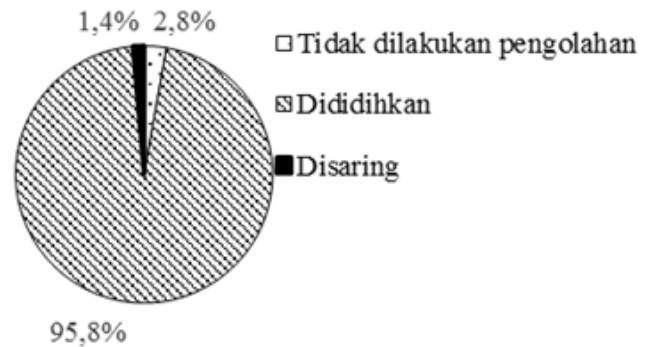

(b)

Gambar 4. Diagram gambaran konsumsi air minum responden. (a) sumber air minum berdasarkan recall 24 jam (b) cara pengolahan air minum.

total $\mathrm{Hg}$ pada spesies ikan sudah melebihi nilai ambang batas $50 \mu \mathrm{g} / \mathrm{g}$ yang direkomendasikan Dirjen POM tahun 1989. Spesies tuna, E. affinis masih berada di bawah ambang batas 46,30 $\pm 2,98$ $\mu \mathrm{g} / \mathrm{g}$. Konsentrasi total $\mathrm{Hg}$ antar spesies ikan penelitian ini berbeda secara signifikan $(\mathrm{p}<0,05)$. Miniero dkk. (2013) menyatakan bahwa perbedaan konsentrasi $\mathrm{Hg}$ antar spesies ikan dipengaruhi beberapa faktor, diantaranya pola makan, sistem metabolisme tubuh, dan mekanisme akumulasi $\mathrm{Hg}$. Tingginya konsentrasi $\mathrm{Hg}$ pada spesies ikan yang dikonsumsi masyarakat Krueng Sabee dapat memengaruhi kesehatan masyarakat setempat. Beberapa penelitian menunjukkan bahwa kebiasaan konsumsi ikan yang mengandung $\mathrm{Hg}$ dapat menyebabkan masuknya logam berbahaya ini ke dalam tubuh manusia dan menyebabkan munculnya keluhan gangguan kesehatan (Abdelouahab dkk., 2008; Cheng dkk., 2009; Salehi dan Esmaili-Sari, 2010).

\section{Gambaran Konsumsi Air Minum}

Berdasarkan data recall 24 jam, responden mengkonsumsi air minum dari sumber PDAM, sumur, galon, dan pegunungan. Sebelum dikonsumsi, air minum terlebih dahulu dilakukan pengolahan. Sumber air minum dan cara pengolahan air minum oleh responden ditampilkan pada Gambar 4.

Sumber air minum responden di wilayah Krueng Sabee paling banyak dari PDAM $(61,1 \%)$ dan sangat sedikit dari sumur (4,2\%). Air yang dikonsumsi responden sebagian besar dilakukan pengolahan dengan dididihkan $(95,8 \%)$ tetapi masih ada yang tidak melakukan pengolahan sebelum diminum $(2,8 \%)$. Hal ini perlu menjadi perhatian karena dengan telah terdeteksinya $\mathrm{Hg}$ di dalam air sumur masyarakat pada penelitian ini maka dapat menyebabkan terjadinya akumulasi $\mathrm{Hg}$ di dalam tubuh mereka. Widowati dkk. (2008) menyatakan dalam lingkungan yang telah tercemar oleh $\mathrm{Hg}$, upaya yang dapat dilakukan untuk penyehatan kembali lingkungan diantaranya adalah pengolahan air yang terpolusi secara fisik atau kimiawi. Perilaku responden untuk mendididihkan air sebelum diminum merupakan upaya pengolahan yang baik dalam meminimalkan pencemar masuk ke dalam tubuh. Untuk tujuan tersebut, diperlukan pula penyuluhan atau peningkatan pemahaman mengenai metode pengolahan air minum yang memenuhi syarat kesehatan.

\section{Konsumsi Seafood}

Gambaran frekuensi konsumsi seafood oleh responden ditunjukkan pada Gambar 5. Berdasarkan gambar ini terlihat frekuensi konsumsi seafood oleh responden tinggi. Sebanyak $69,40 \%$ responden mengkonsumsi seafood sedikitnya 1 kali sehari, bahkan hanya $1,40 \%$ yang tidak pernah makan seafood. Namun demikian, penelitian ini mendapatkan tidak adanya hubungan antara frekuensi makan seafood dengan konsentrasi $\mathrm{Hg}$ di 


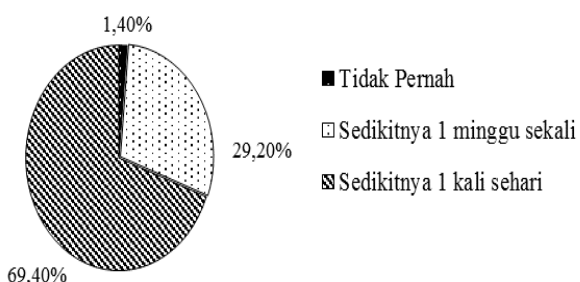

Gambar 5. Diagram gambaran frekuensi konsumsi seafood.

dalam rambut kepala $(p=0,123)$. Hasil ini sesuai dengan penelitian Kwaansa-Ansah dkk. (2010) yang menemukan rerata konsumsi ikan mingguan tidak berkorelasi signifikan dengan konsentrasi $\mathrm{Hg}$ di rambut kepala $(\mathrm{p}>0,05)$. Namun beberapa penelitian lain menunjukkan hasil yang berbeda. Ramos dkk. (2014) menyatakan bahwa penduduk yang mengkonsumsi ikan $<1$ hari/minggu memiliki konsentrasi $\mathrm{Hg}$ lebih rendah dibandingkan penduduk yang mengkonsumsi ikan 1 hari hingga di atas 6 hari/minggu $(p<0,05)$. Penelitian yang dilakukan oleh Rizal (2003) dan Sudarmaji dkk. (2004) mendapatkan bahwa konsumsi makanan yang mengandung $\mathrm{Hg}$ mampu meningkatkan jumlah $\mathrm{Hg}$ di dalam tubuh manusia. Hal ini menekankan perlu adanya kewaspadaan bagi masyarakat yang memiliki kebiasaan mengkonsumsi seafood untuk lebih memperhatikan sumber seafood yang dimakan.

\section{Konsentrasi Merkuri di dalam Rambut Kepala}

Berdasarkan lokasi, konsentrasi total $\mathrm{Hg}$ ratarata di dalam rambut kepala responden bervariasi seperti ditampilkan pada Gambar 6. Gambar tersebut menunjukkan konsentrasi total $\mathrm{Hg}$ rata-rata tertinggi tercatat pada responden dari desa Paya Seumantok $(48,30 \pm 22,29 \mu \mathrm{g} / \mathrm{g})$ dan terendah dari desa Curek $(11,20 \pm 4,02 \mu \mathrm{g} / \mathrm{g})$. Secara keseluruhan, sebanyak $90,28 \%$ responden dari empat lokasi penelitian didapati mengandung $\mathrm{Hg}$ di dalam rambut kepala di atas nilai ambang batas 10 $\mu \mathrm{g} / \mathrm{g}$ yang ditetapkan WHO. Hal ini dapat dijelaskan bahwa lokasi Paya Seumantok lebih dekat jaraknya dengan sungai, yaitu $0,49 \mathrm{~km}$ yang memiliki jumlah industri pengolah emas yang beroperasi lebih banyak (21 industri). Meskipun desa Panggong memiliki jarak yang dekat dengan sungai, sekitar $0,35 \mathrm{~km}$ dan jumlah industri yang banyak (31 industri) namun letak lokasi desa Panggong secara geografis lebih tinggi dibandingkan desa Paya Seumantok. Keadaan ini memberi peran terhadap penerimaan buangan limbah $\mathrm{Hg}$ dari kegiatan PESK yang berasal dari desa Panggong dan desa Curek. Aliran buangan limbah $\mathrm{Hg}$ akan lebih besar menuju desa Paya

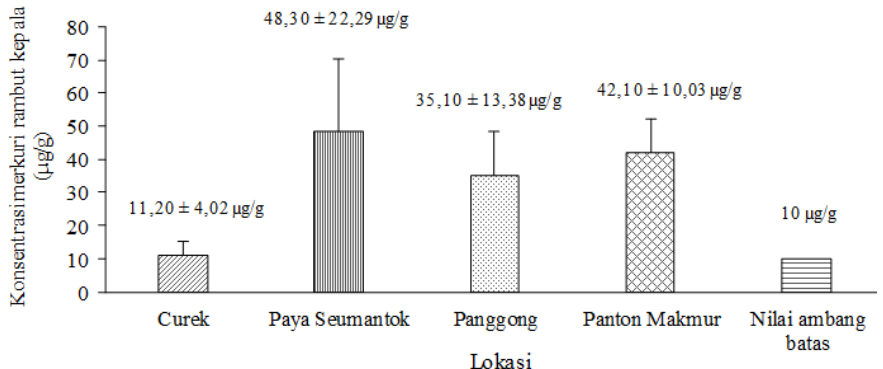

Gambar 6. Konsentrasi total $\mathrm{Hg}$ di dalam rambut kepala responden pada tiap lokasi desa dibandingkan nilai ambang batas.

Seumantok sehingga akumulasi $\mathrm{Hg}$ pada air sungai dan air tanah semakin tinggi pada lokasi ini. Selain itu, aktivitas pembakaran amalgam yang dilakukan pekerja tambang di desa Paya Seumantok lebih aktif dibandingkan di desa Panggong, desa Curek dan desa Panton Makmur. Kadar merkuri yang tinggi pada rambut kepala responden di desa Paya Seumantok menunjukkan merkuri sudah terakumulasi di dalam tubuh responden. Srogi (2007) mempelajari aktivitas PESK pada populasi Asia dan menemukan bahwa perbedaan yang terjadi terhadap kadar merkuri di dalam rambut kepala responden dipengaruhi oleh faktor keberagaman ekologi, masyarakat, keluarga, sikap individu dan cara pemakanan. Untuk mengatasinya diperlukan monitoring berkelanjutan untuk menghindari terjadinya gangguan lebih buruk pada kesehatan manusia yang tinggal di daerah ini baik dengan mengenalkan teknologi bebas $\mathrm{Hg}$ maupun dengan melakukan edukasi pada masyarakat dan pekerja tentang bahaya penggunaan $\mathrm{Hg}$ dalam aktivitas PESK.

\section{Faktor-faktor Risiko Kegiatan PESK}

Faktor-faktor risiko yang memengaruhi konsentrasi total $\mathrm{Hg}$ di dalam rambut kepala responden ditampilkan pada Tabel 1. Data menunjukkan responden banyak berumur 26-45 tahun (96,44\%), jenis kelamin lelaki (39\%), bekerja sebagai penambang $(36,11 \%)$, lokasi tinggal paling banyak di Paya Seumantok (36,11\%), lama tinggal di wilayah Krueng Sabee $>20$ tahun (51,39\%), banyak yang bekerja di Krueng Sabee $(68,06 \%)$, sebagian responden bekerja sebagai pekerja tambang $(63,89 \%)$, dan yang melakukan proses pembakaran amalgam hanya 12 orang dengan waktu paling lama melakukan pembakaran $<5$ tahun $(13,89 \%)$. Analisis bivariat variabel faktorfaktor risiko yang memengaruhi kadar $\mathrm{Hg}$ di dalam rambut kepala tidak menunjukkan ada hubungan secara signifikan, namun lokasi responden menunjukkan ada hubungan signifikan ( $\mathrm{p}<0,05)$. Hal yang dapat dijelaskan dari penelitian ini bahwa tingginya konsentrasi $\mathrm{Hg}$ pada manusia dipengaruhi 
oleh faktor-faktor yang tidak bisa ditinjau secara terpisah satu sama lain namun kajian variabelvariabel faktor risiko harus ditinjau secara bersamaan.

\section{Model Prediksi Kadar Merkuri}

Model prediksi $\mathrm{Hg}$ di dalam rambut kepala responden dilakukan dengan memasukkan variabel kandidat yang diuji pada analisis bivariat yang selanjutnya dianalisis secara bersama-sama. Variabel-variabel yang memiliki peran terhadap masuknya merkuri ke dalam tubuh responden adalah lokasi desa, status bekerja di Krueng Sabee, lama tinggal di Krueng Sabee, status pekerja tambang, dan lama penggunaan pembakar amalgam. Kriteria variabel statistik yang ditinjau dalam model tertera pada Tabel 2.

Kriteria nilai koefisien determinasi terkoreksi menunjukkan bahwa variabel penelitian ini mampu memberi ketepatan yang cukup dalam menghasilkan model yang baik. Nilai tersebut juga menunjukkan variabel yang dimasukkan di dalam model telah memberi peran sebesar $45,8 \%$ terhadap konsentrasi merkuri di dalam rambut kepala responden. Kekuatan hubungan antar variabel bebas diketahui dari nilai koefisien determinasi, yang memiliki kekuatan hubungan dengan tingkat

Tabel 1. Faktor-faktor risiko yang memengaruhi konsentrasi Hg responden.

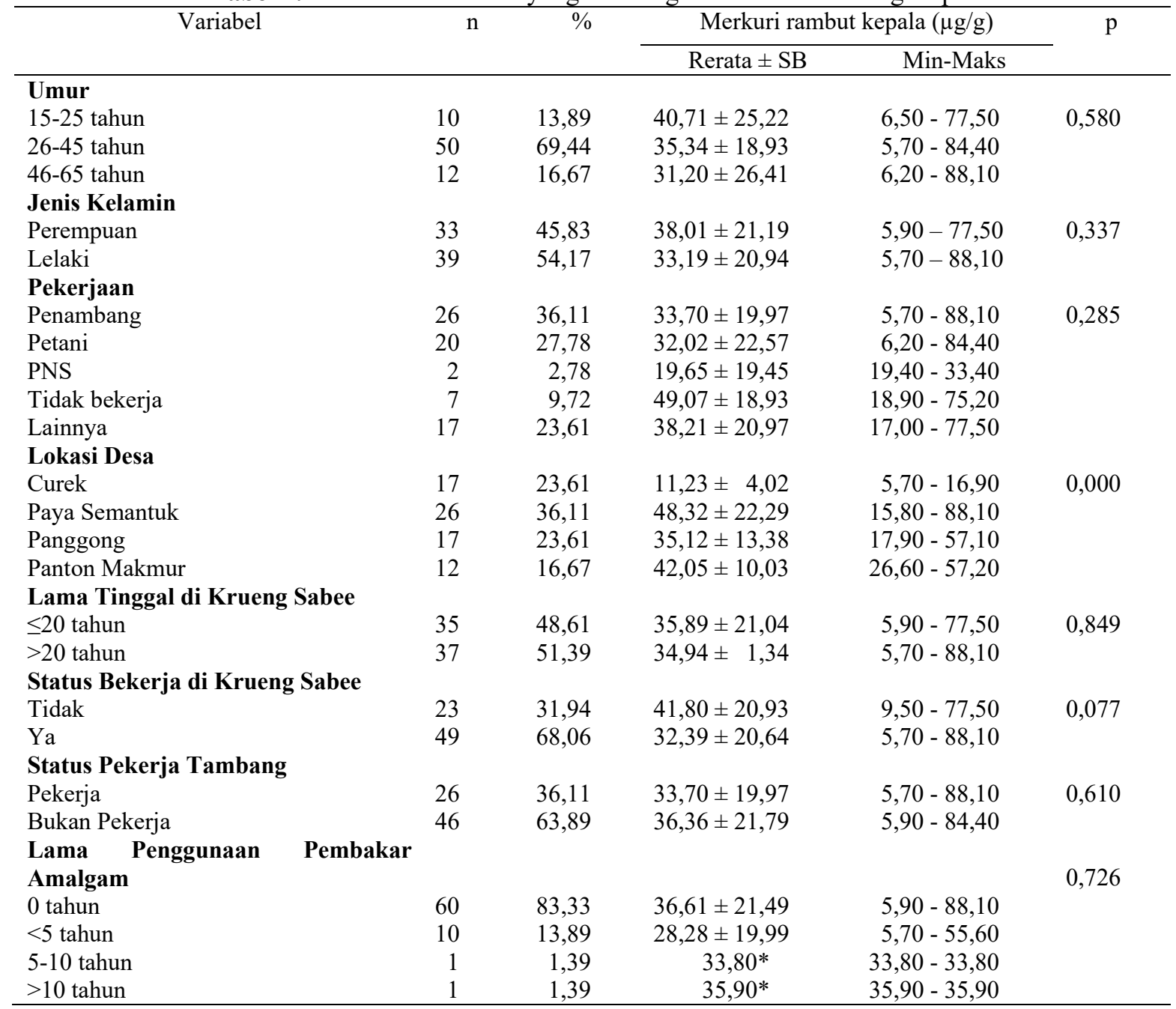

Sumber : Data primer.

Ket.: $\mathrm{SB}=$ simpangan baku; Min-Maks=minimum-maksimum. ${ }^{*} \mathrm{SB}$ tidak dihitung pada $\mathrm{n}=1$

Tabel 2. Kriteria statistik model prediksi Hg.

\begin{tabular}{cccccc}
\hline $\begin{array}{c}\text { Variabel } \\
\text { Statistik }\end{array}$ & $\begin{array}{c}\text { Koefisien korelasi } \\
\text { berganda }\end{array}$ & $\begin{array}{c}\text { Koefisien } \\
\text { determinasi }\end{array}$ & Signifikan & $\begin{array}{c}\text { Koefisien determinasi } \\
\text { terkoreksi }\end{array}$ & $\begin{array}{c}\text { Simpangan baku dari } \\
\text { penduga }\end{array}$ \\
\hline Nilai & 0,715 & 0,512 & 0,000 & 0,458 & 15,495 \\
\hline
\end{tabular}

Sumber : Data primer. 
sedang $(r=0,512)$. Persamaan matematis dari model prediksi yang diperoleh adalah :

$\mathrm{Y}=42,808-8,566(\mathrm{X} 1)-30,300(\mathrm{X} 2)+7,467$ (X3)$9,053(\mathrm{X} 4)+0,140(\mathrm{X} 5)+6,926(\mathrm{X} 6)-0,754(\mathrm{X} 7)$

Keterangan:

$\mathrm{Y}=$ konsentrasi $\mathrm{Hg}$ di dalam rambut kepala; $\mathrm{X} 1=$ bekerja di Krueng Sabee; X2 = desa Curek; X3 = desa Paya Seumantok; X4 = desa Panggong; X5 = lama tinggal di Krueng Sabee; $X 6=$ pekerja tambang; $\mathrm{X} 7=$ lama penggunaan pembakar amalgam

Model prediksi ini dapat digunakan sebagai formula untuk memprakirakan konsentrasi $\mathrm{Hg}$ pada manusia yang tinggal di wilayah Krueng Sabee Aceh Jaya, Provinsi Aceh. Model ini dapat menjadi penilaian awal bagi individu dalam menentukan status kesehatannya.

\section{KESIMPULAN}

Konsentrasi $\mathrm{Hg}$ di dalam air sumur dan PDAM tidak melebihi 1 ppb dari Peraturan Pemerintah No 82 Tahun 2001. Kadar Hg di dalam ikan sudah melebihi nilai ambang batas $0,05 \mathrm{ppm}$ dari Dirjen POM tahun 1989. Sebanyak 90,28\% responden dari empat lokasi penelitian ini didapati mengandung $\mathrm{Hg}$ di atas nilai ambang batas $10 \mu \mathrm{g} / \mathrm{g}$ yang ditetapkan WHO. Model prediksi yang ditemukan untuk faktor-faktor risiko yang memengaruhi konsentrasi merkuri di dalam rambut kepala responden di wilayah Krueng Sabee yaitu faktor risiko status bekerja di Krueng Sabee, lokasi desa, lama tinggal di Krueng Sabee, status pekerja tambang dan lama penggunaan pembakar amalgam.

\section{UCAPAN TERIMAKASIH}

Penulis mengucapkan terima kasih atas dukungan dana melalui Program PHK-PKPD HPEQ Universitas Syiah Kuala dan Staf Laboratorium Makmal Unit Perkhidmatan Analisis (MUPA) Pusat Pengajian Kimia, Universiti Sains Malaysia atas fasilitas pengujian sampel.

\section{DAFTAR PUSTAKA}

Abdelouahab, N., Vanier, C., Baldwin, M., Garceau, S., Lucotte, M., dan Mergler, D., 2008. Ecosystem Matters: Fish Consumption, Mercury Intake and Exposure Among Fluvial Lake Fish-Eaters. Sci. Total. Environ., 407:154-164.
Andri, D.H., Anies, dan Suharyo, H., 2011. Kadar Merkuri pada Rambut Masyarakat di Sekitar Penambangan Emas Tanpa Ijin. M. Med. Indones., 45(3):181-187.

Anonim, 1992. Standard Methods for the Examination of Water and Wastewater. $18^{\text {th }}$ ed. APHA. Washington D.C: American Water Works Association and Water Environment Federation.

Anonim, 1995. Guidance for Assessing Chemical Contaminant Data for Use in Fish Advisories. Volume 1: Fish Sampling and Analysis. EPA. Center for Environmental Analysis. Washington D.C.

Anonim, 2008. Mercury: Assessing the Burden of Disease at National and Local Levels. Environmental Burden of Disease Series, No.16. Geneva:WHO. Website: http://whqlibdoc.who.int/publications/2008/97 89241596572_eng.pdf (Accessed: 6 Juni 2015).

Charles, E., Thomas, D.S.K., Dewey D., Davey, M., Ngallaba, S.E., dan Konje, E., 2013. A Cross-Sectional Survey on Knowledge and Perceptions of Health Risks Associated with Arsenic and Mercury Contamination from Artisanal Gold Mining in Tanzania. BMC Public Health. 13:74.

Cheng, J., Gao, L., Zhao, W., Liu, X., Sakamoto, M., dan Wang, W., 2009. Mercury Levels in Fisherman and Their Household Member in Zhoushan, China: Impact of Public Health. Sci. Total. Environ. 407:2625-2630.

Clarkson, T.W., 2002. The Three Modern Faces of Mercury. Environ. Health Perspect. 110 Suppl.1:11-23.

De Miguel, E., Clavijo, D., Ortega, M.F., dan Gomez, A., 2014. Probabilistic Meta-Analysis of Risk from the Exposure to $\mathrm{Hg}$ in Artisanal Gold Mining Communities in Columbia. Chemosphere, 108:183-189.

Elvince, R., Kawakami, T., Serikawa, Y., Nagafuchi, O., Inoue, T., dan Syamsidik, 2010. Mercury Contamination in the Atmosphere and River Water by Small-Scale Gold Mining Plants in Aceh Province, Indonesia. In: $5^{\text {th }}$ Annual International Workshop \& Expo on Sumatra Tsunami Disaster \& Recovery. Aceh. p.208-211.

Knight, R., Haswell, S.J., Lindow, S.W., dan Batty, J., 1999. Determination of Mercury in Hair by Coupled CVAA-ICP-MS. J. Anal. At. Spectrom., 14:127-129.

Kwaansa-Ansah, E.E., Basu, N., dan Nriagu, J.O., 2010. Environmental and Occupational Exposures to Mercury Among Indigenous 
People in Dunkwa-On-Offin, A Small Scale Gold Mining Area in The South-West of Ghana. Bull. Environ. Contam. Toxicol., 85:476-480.

Lee, K.J., dan Lee, T.G., 2012. A Review of International Trends in Mercury Management and Available Options for Permanent or LongTerm Mercury Storage. Jounal of Hazardous Materials, 241-242:1-13.

Miniero, R., Beccaloni, E., Carere, M., Ubaldi, A., Mancini, L., Marchegiani, S., Cicero, M.R., Scenati,R., Lucchetti, D., Ziemacki, G., dan De Felip, E., 2013. Mercury (Hg) and Methyl Mercury (MeHg) Concentrations in Fish from the Coastal Lagoon of Orbetello, Central Italy. Mar. Pollut. Bull., 76:365-369.

Olivero-Verbel, J., Caballero-Gallardo, K., dan Negrete-Marrugo, J., 2011. Relationship Between Localization of Gold Mining Areas and Hair Mercury Levels in People from Bolivar, North of Colombia. Biol. Trace Elem. Res. 144:118-132.

Ramos, A., Penelope, J.E., Quintana, Q., dan Ji, M., 2014. Hair Mercury and Fish Consumption In Residents of O'ahu, Hawai'i. Hawai'i Journal of Medicine and Public Health, 73:19-25.

Rizal, A., 2003. Kadar Merkuri Rambut Kepala dan Faktor-Faktor yang Mempengaruhinya Pada Penduduk Kelurahan Tangkiling Kecamatan Bukit Batu Kota Palangkaraya. Tesis. Program Studi IKM Program Pascasarjana, Universitas Gadjah Mada, Yogyakarta.

Salehi, Z., dan Esmaili-Sari, A., 2010. Hair Mercury Levels in Pregnant Women in Mahshahr, Iran: Fish Consumption as A Determinant Of Exposure. Sci. Total Environ., 408:4848-4854.

Shandro, J.A., Veiga, M.M., dan Chouinard, R., 2009. Reducing Mercury Pollution from
Artisanal Gold Mining in Munhena, Mozambique. Journal of Cleaner Production, 17:525-532.

Spiegel, S.J., dan Veiga, M.M., 2005. Building Capacity in Small-Scale Mining Communities: Health, Ecosystem Sustainability, and the Global Mercury Project. EcoHealth., 2:361369.

Srogi, K., 2007. Mercury Content of Hair in Different Populations Relative to Fish Consumption. Rev. Environ. Contam. Toxicol., 189:107-130.

Sudarmaji, Sutomo, A.H., dan Suwarni, A. 2004. Konsumsi Ikan Laut, Kadar Merkuri dalam Rambut, dan Kesehatan Nelayan di Pantai Kenjeran Surabaya. J. Manusia dan Lingkungan. 11(3):134-142.

Suharno, Sancayaningsih, R.P., Sutariningsih, E.S, dan Kusmandari, R.K., 2014. Keberadaan Fungsi Mikoriza Arbuskula di Kawasan Tailing Tambang Emas Timika Sebagai Upaya Rehabilitasi Lahan Ramah Lingkungan. J. Manusia dan Lingkungan. 21(3):295-303.

Suhendrayatna, Ohki, A., dan Gultom, A.C., 2011. Mercury Levels and Distribution in Organs of Freshwater Organisms from Krueng Sabe River, Aceh Jaya, Indonesia. In: $6^{\text {th }}$ Annual International Workshop \& Expo on Sumatra Tsunami Disaster \& Recovery in Conjuction with $4^{\text {th }}$ South China Sea Tsunami Workshop. ISSN: 2086-3195. Banda Aceh. November 2224, 2011. p. 291-294.

Swain, E.B., Jakus, E.M., Lupi, F., Maxson, P.A., dan Pacyna, J.M., 2007. Socioeconomic Consequences of Mercury Use and Pollution. Ambio., 36:46-61.

Widowati, W., Sastiono, A., dan Jusuf, R., 2008. Efek Toksik Logam. Penerbit Andi. Yogyakarta. 